\title{
How creative is the crowd in describing smart home scenarios?
}

\section{Citation for published version (APA):}

Abbas, T., Khan, J. V., Tetteroo, D., \& Markopoulos, P. (2018). How creative is the crowd in describing smart home scenarios?. Poster session presented at $2018 \mathrm{CHI}$ Conference on Human Factors in Computing Systems, CHI 2018, Montreal, Canada.

\section{Document status and date:}

Published: 01/01/2018

\section{Document Version:}

Publisher's PDF, also known as Version of Record (includes final page, issue and volume numbers)

\section{Please check the document version of this publication:}

- A submitted manuscript is the version of the article upon submission and before peer-review. There can be important differences between the submitted version and the official published version of record. People interested in the research are advised to contact the author for the final version of the publication, or visit the $\mathrm{DOI}$ to the publisher's website.

- The final author version and the galley proof are versions of the publication after peer review.

- The final published version features the final layout of the paper including the volume, issue and page numbers.

Link to publication

\section{General rights}

Copyright and moral rights for the publications made accessible in the public portal are retained by the authors and/or other copyright owners and it is a condition of accessing publications that users recognise and abide by the legal requirements associated with these rights.

- Users may download and print one copy of any publication from the public portal for the purpose of private study or research.

- You may not further distribute the material or use it for any profit-making activity or commercial gain

- You may freely distribute the URL identifying the publication in the public portal.

If the publication is distributed under the terms of Article 25fa of the Dutch Copyright Act, indicated by the "Taverne" license above, please follow below link for the End User Agreement:

www.tue.nl/taverne

Take down policy

If you believe that this document breaches copyright please contact us at:

openaccess@tue.nl

providing details and we will investigate your claim. 
TU/e

Technische Universiteit Eindhoven

University of Technology
How Creative is the Crowd in Describing Smart Home

Scenarios?

Tahir Abbas ${ }^{1,2}$; Vassilis-Javed Khan ${ }^{1}$; Daniel Tetteroo ${ }^{1}$; Panos Markopoulos ${ }^{1}$

${ }^{1}$ Eindhoven University of Technology, Eindhoven, the Netherlands, ${ }^{2}$ Mirpur University of Science \& Technology (MUST), Mirpur-10250, AJK Pakistan

\section{Abstract}

Internet of Things (IOT) is recently attracting vendors that have already brought to the market a plethora of loT devices. However, according to recent studies;

- End-users face difficulties in conjuring up meaningful use scenarios that combine loT devices

- Information provided by loT vendors on their websites does not help consumers to translate their high-level goals to useful scenarios

We present an on-going investigation that explores the potential of sourcing loT-relevant scenarios from a popular microtaskcrowdsourcing platform, and a preliminary evaluation of such scenarios with respect to their originality and practicality.

\section{Motivation}

Our main motivation was to check the feasibility of a pipeline where end-users can select some smart home devices and then system generate several loT scenarios in various categories based on selected devices.

However, there are several questions that arise:

- Where should these pre-defined scenarios come from?

- How can vendors anticipate and gather useful scenarios and provide them on their websites?

- How can inexperienced inhabitants, who are already living in smart homes and want to grow their system with new devices, get useful ideas?

In this research we examine whether crowdsourcing could be a suitable approach to collecting and organizing such scenarios.

\begin{tabular}{|c|c|}
\hline \multicolumn{2}{|c|}{ Methods and Materials } \\
\hline $\begin{array}{l}\text { (Step - 1) } \\
\text { Generate Scenarios (306) } \\
\text { By crowd through Mturk (102) }\end{array}$ & Two independent experts \\
\hline 5 & $\begin{array}{l}\text { randomly selected } \\
\text { scenarios on a two 7-point }\end{array}$ \\
\hline $\begin{array}{c}(\text { Step - 2) } \\
\text { Creativity Evaluation (40) } \\
\text { By experts (2) }\end{array}$ & $\begin{array}{l}\text { Likert scales using the } \\
\text { binary measures of } \\
\text { creativity (an idea should }\end{array}$ \\
\hline 5 & be both original and \\
\hline $\begin{array}{c}\text { (Step - 3) } \\
\text { Identification of Properties } \\
\text { (e.g. word count, devices } \\
\text { count etc.) }\end{array}$ & Cosine similarity is a \\
\hline L & $\begin{array}{l}\text { vector-based measure of } \\
\text { the similarity of two }\end{array}$ \\
\hline $\begin{array}{c}\text { (Step - 4) } \\
\text { Similarity Measures } \\
\text { By TF-IDF and Cosine } \\
\text { Similarity }\end{array}$ & $\begin{array}{l}\text { strings. In this method, we } \\
\text { transform each string into } \\
\text { a high dimensional vector }\end{array}$ \\
\hline 3 & $\begin{array}{l}\text { space in which strings } \\
\text { which are closer to each }\end{array}$ \\
\hline $\begin{array}{l}(\text { Step }-5) \\
\text { Reporting determinants of } \\
\text { Creativity }\end{array}$ & $\begin{array}{l}\text { other are considered more } \\
\text { similar and vice versa }\end{array}$ \\
\hline
\end{tabular}

Contact: Tahir Abbas

Industrial Design

Eindhoven University of Technology, the Netherlands t.abbas@tue.nl

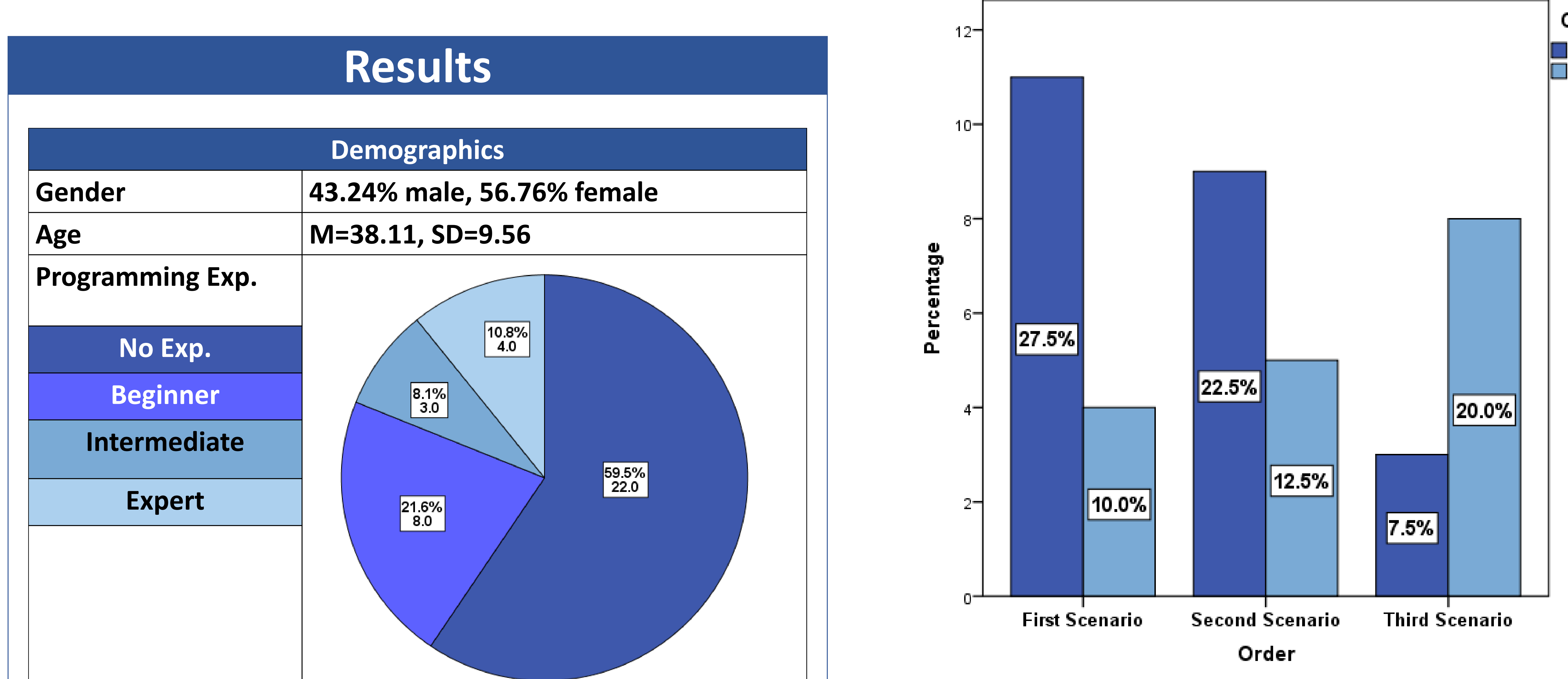

Smart Home Exp.

48.6\% had smart home experience

Categories:

Distribution of categories in which workers classified their scenarios. It closely resembles a bimodal distribution with Home Security and Comfort topping the list. The Other category includes user defined categories e.g. Pet Care, Entertainment, Child Care and Cleaning.

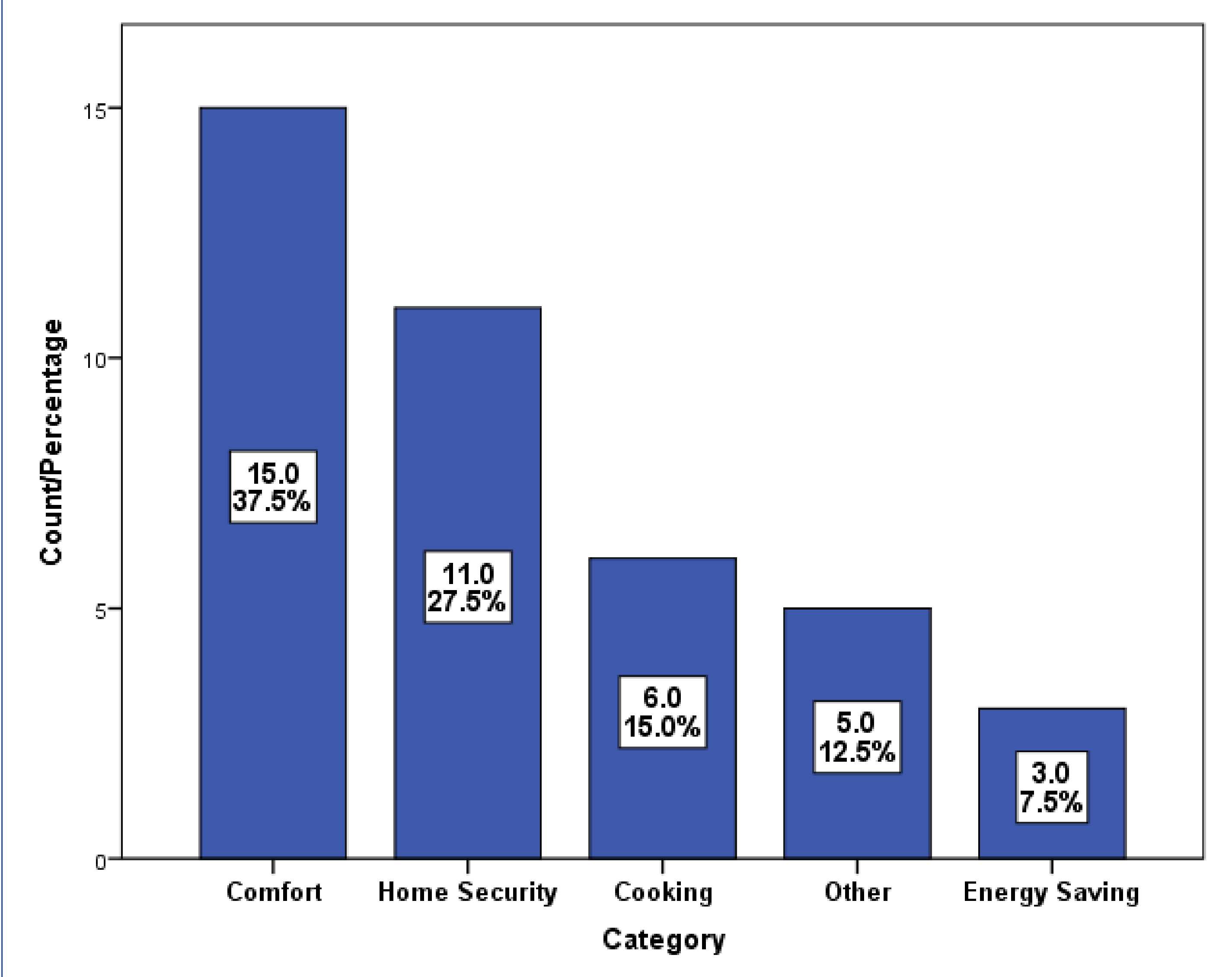

Correlates of Originality and Practicality:

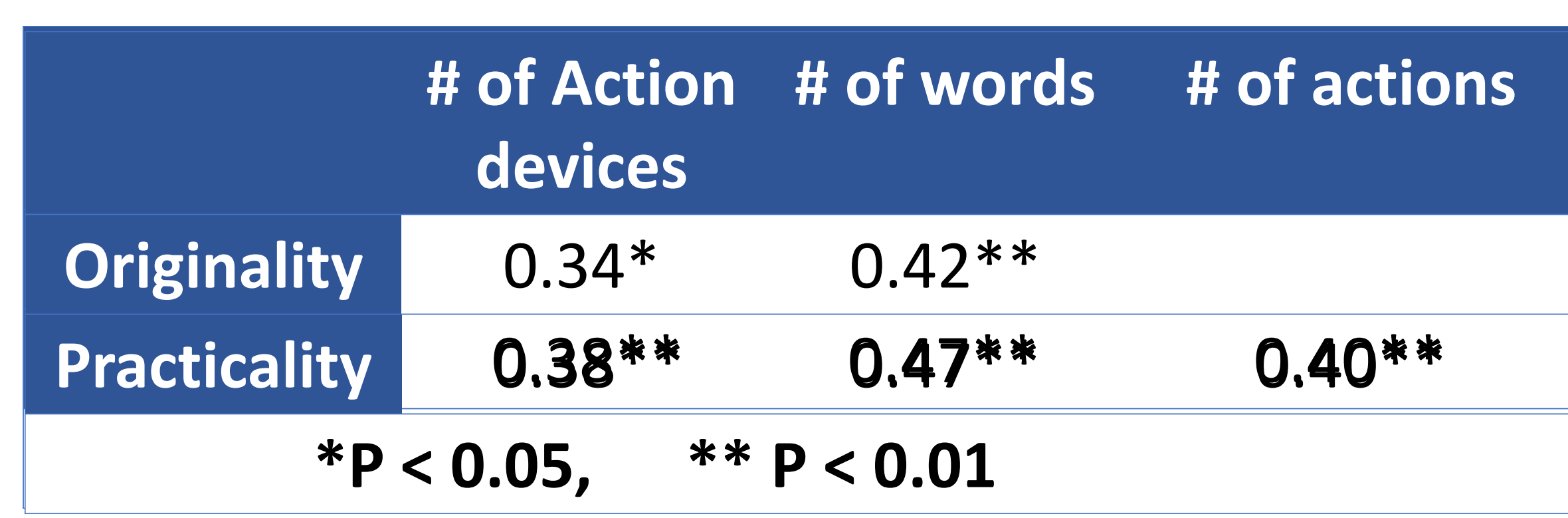

We also found a weak inverse correlation between subjective evaluation of originality by experts and objective evaluation by cosine based similarity measures $(r=-0.10, p=0.542)$.
We found that the overall creativity increased with each subsequent scenario $\chi^{2}(1, N=40)=5.06, p<0.05$

\section{Conclusions}

- In this paper, we reported some preliminary results based on the analysis that we conducted on a data set of IoT application scenarios collected with MTurk.

We evaluated these scenarios on various dimensions finding interesting correlations between creativity and different features of scenarios like word count, number of devices used and their actions, and the order in which workers wrote scenarios.

\section{Future Work}

- In Future, we will build a system that allows end-users to just define trigger and action devices, and the system on the background will crowdsource creative scenarios in different categories.

- We have also planned to evaluate the crowd created scenarios from actual owners- smart home inhabitants and loT vendors.

- In addition to that we will build a recommender system for smart home's inhabitants that can recommend use case scenarios based on preferences and other traits.

\section{Acknowledgement}

- This work was supported by the Mirpur University of Science \& Technology (MUST)-10250, Mirpur AJK, Pakistan under award No. 611-19 P.D/2017.

- The first author of this paper was also financially supported by SIGCHI student travel grant for attending CHI 2018 conference.

Link to paper:

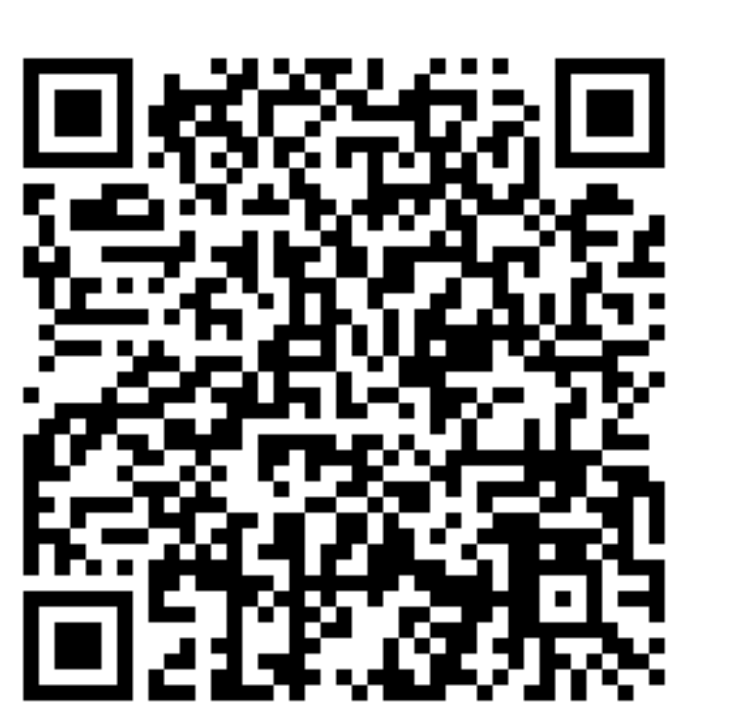

Link to video preview: 